Nevşehir Bilim ve Teknoloji Dergisi Cilt 4(2) 1-8 2015

DOI: $10.17100 /$ nevbiltek.210944

URL: http://dx.doi.org/10.17100/nevbiltek.210944

\title{
Callus Induction and Adventitious Shoot Regeneration of Centaurea zeybekii Wagenitz: Endangered Endemic Plant
}

\author{
Serap Kurt Aydoğan ${ }^{1}$, Bengi Baba Erdağ ${ }^{1 *}$ \\ ${ }^{1}$ Department of Biology, Faculty of Arts \& Sciences, Adnan Menderes University, 09010, Aydın, Turkey
}

\begin{abstract}
In this paper we reported the effect of different cytokinins on callus induction and adventitious shoot regeneration from leaf segments of in vitro grown Centaurea zeybekii Wagenitz seedlings.

Callus was not induced when the explants were cultured on MS medium devoid of any growth regulators. Callus formation was observed in MS media containing TDZ, BA and KIN. The highest callusing response was observed in the media containing $0.005 \mathrm{mg} / \mathrm{Land} 0.01 \mathrm{mg} / \mathrm{L}$ TDZ (100\%). In adventitious shoot induction experiments, well developed shoots were observed only MS media supplemented with KIN at the end of sixth week. The highest number of shoot per explant was obtained from the MS medium containing $1 \mathrm{mg} / \mathrm{LKIN}$ (6.2 shoots/explant). The highest average of maximum shoot length was also observed in this medium $(4.17 \mathrm{~cm})$. There was no difference between MS and $1 / 2$ MS media in rooting but it was very low and only $15 \%$ of total shoots could rooted in medium containing $0.5 \mathrm{mg} / \mathrm{L}$ IBA.
\end{abstract}

Key words: Centaurea zeybekii, endemic, callus, adventitious shoot

\section{Tehlike Altındaki Endemik Bitki Centaurea zeybekii Wagenitz 'nin Kallus İndüksiyonu ve Adventif Sürgün Rejenerasyonu}

$\ddot{O} \mathbf{z}$

Bu çalı̧̧mada in vitro büyütülmüş Centaurea zeybekii Wagenitz fidelerinin yaprak parçalarından kallus indüksiyonu ve adventif sürgün rejenerasyonu üzerine farklı sitokininlerin etkisi rapor edilmiștir.

Eksplantlar herhangi bir büyüme düzenleyicisi içermeyen MS ortamına kültüre edildikleri zaman kallus oluşumu gerçekleşmemiştir. Kallus oluşumu TDZ, BA ve KIN içeren MS ortamlarında gözlenmiştir. En yüksek kalluslaşma cevabı 0.005 mg/L ve $0.01 \mathrm{mg} / \mathrm{L}$ TDZ (\% 100) içeren ortamlarda gözlenmiştir. Adventif sürgün indüksiyonu denemelerinde, iyi gelişmiş sürgünler altıncı haftanın sonunda sadece KIN içeren MS ortamında gözlenmiştir. Eksplant başına en yüksek sürgün sayısı $1 \mathrm{mg} / \mathrm{L} \mathrm{KIN} \mathrm{(6.2} \mathrm{sürgün/eksplant)} \mathrm{içeren} \mathrm{MS} \mathrm{ortamından} \mathrm{elde}$ edilmiştir. Maksimum sürgün boyunun en yüksek ortalaması da aynı ortamda gözlenmiştir $(4.17 \mathrm{~cm})$. Köklenme açısından MS ve $1 / 2 \mathrm{MS}$ ortamları arasında fark yoktur. Ancak köklenme çok düşüktür ve total sürgünlerin sadece \% 15 'i $0.5 \mathrm{mg} / \mathrm{L}$ IBA içeren ortamda köklendirilebilmişlerdir.

Anahtar sözcükler: Centaurea zeybekii, endemik, kallus, adventif sürgün

\footnotetext{
*e-mail: berdag@adu.edu.tr
} 


\section{Introduction}

Turkey has an enourmous biodiversity due to its geological, climatological and ecological properties. Nearly $30 \%$ of Turkish Flora are known to be rare, endemic or threatened and require proper management practices to conserve germplasm.

Centaurea zeybekii Wagenitz, belonging to the family Asteraceae, is an endemic species and has been indicated as EN (Endangered) taxa in Red Data Book of Turkish Plants [1]. This species is known only from its type locality in Nif mountain, nearly $30 \mathrm{~km}$ east of İzmir city of Western Turkey. The population consist of small numbers of speciments. C. zeybekii prefers forest openings and road sides as a ruderal species.

Besides conventional methods of propagation, plant tissue culture techniques represent an excellent option for the study and conservation of threatened or endangered species [2-5]. Some species of the genus Centaurea have been succesfully propagated using these techniques [6-8]. In relevant literature, there is only report on in vitro culture of Centaurea zeybekii. In this report, in vitro germination and axillary shoot propagation of this species has been described by Kurt and Erdağ [9].

Additionally, most of the Centaurea species are known their medical applications in folk medicine [1012]. Constituents of essential oils of $C$. zeybekii has been studied by Altıntaş et al. and they reported that hexanoic asit $(9.3 \%)$, hexadecanoic acid $(8.6 \%)$ and nonacosane $(6.4 \%)$ are the main components of this essential oils[13]. Additionally Kurt et al. studied antioxidant activity of the species and they concluded that this species may serve as a source for natural antioxidants[14].

The aim of this study was to develop methods for callus induction and adventitious shoot regeneration from leaf explants of seedlings germinated in vitro of C. zeybekii is an endangered endemic species, as a contribution to its conservation efforts and biotechnological uses in future.

\section{Materials and Methods}

Leaf explants were used as initial materials for experiments on callus induction and adventitious shoot regeneration. Mature seeds (achenes) were collected from natural habitat on August. Seeds were sterilized and germinated on distilled water supplemented with various vitamines and $1 \mathrm{mg} / \mathrm{L} \mathrm{GA}_{3}$ as described by Kurt and Erdağ [9]. Germinated seeds were transferred to Murashige and Skoog (MS) [15] medium containing $30 \mathrm{~g} \mathrm{~L}^{-1}$ sucrose to development of seedlings. The $\mathrm{pH}$ of all media was adjusted to 5.8 with $0.1 \mathrm{~N} \mathrm{NaOH}$ and $0.1 \mathrm{~N} \mathrm{HCI}$ before adding $8 \mathrm{gL}^{-1}$ agar-agar (Merck). Medium was distributed into baby jars $(210 \mathrm{cc})$. The jars filled $25 \mathrm{ml}$ of medium were autoclaved at $105 \mathrm{kPa}$ and $121{ }^{\circ} \mathrm{C}$ for 15 minutes. Leaves from of 4 weeks old seedlings were cut two times and explants were cultured on MS medium supplemented with 6-benzyladenine (BA; 0.2, 0.5, 1 and 2 $\mathrm{mg} / \mathrm{L}$ ), Kinetin (KIN; 0.2, 0.5, 1 and $2 \mathrm{mg} / \mathrm{L}$ ) or Thidiazuron (TDZ; 0.001, 0.005, 0.01 and $0.02 \mathrm{mg} / \mathrm{L}$ ) to determine the optimum concentration of plant growth regulators on callus induction and adventitious shoot regeneration.

The experiments were conducted with five replicates consisting of four explant per flask and all experiments were repeated twice. Explants were placed abaxial sides in contact with the regeneration media. The cultures were incubated in a growth chamber at $24 \pm 2{ }^{\circ} \mathrm{C}$ with illumunation provided by cool white fluorescent lamps at $40 \mu \mathrm{E} \mathrm{m} \mathrm{m}^{-2}$ with a 16-h light photoperiod. Subcultures to medium with the same 
composition were performed at 4 week intervals. The callusing response (\%), the number of shoots per explant and shoot length were recorded 6 week after the induction period.

Shoots (3-4 $\mathrm{cm}$ long) were recorded individualized and transferred to rooting medium containing full and half strength MS salts supplemented with $0.5,1,2$ and $5 \mathrm{mg} / \mathrm{L}$ IAA, IBA or NAA. Results of rooting experiments were expressed in percentage. Root induction responses were evaluated 6 week after the induction period.

\section{Results}

Callus was not induced when the explants were cultured on MS medium devoid of any growth regulators. When the leaf explants were inoculated on MS media supplemented with cytokinins callus formation was observed. The highest callusing response (\%) was observed in the media containing $0.005 \mathrm{mg} / \mathrm{Land} 0.01$ $\mathrm{mg} / \mathrm{LTDZ}$, it was decreased in the media containing $0.02 \mathrm{mg} / \mathrm{LTDZ}$ (Figure 1). During the experiments, different structure calli types were observed. The most of calli from tip parts of explants were green color and have organogenic structure, but at lower rates of calli especially from the proximal parts of explants were pale yellow and embryogenic structure in the medium with $0.005 \mathrm{mg} / \mathrm{L} \mathrm{TDZ}$ (Figure 2).

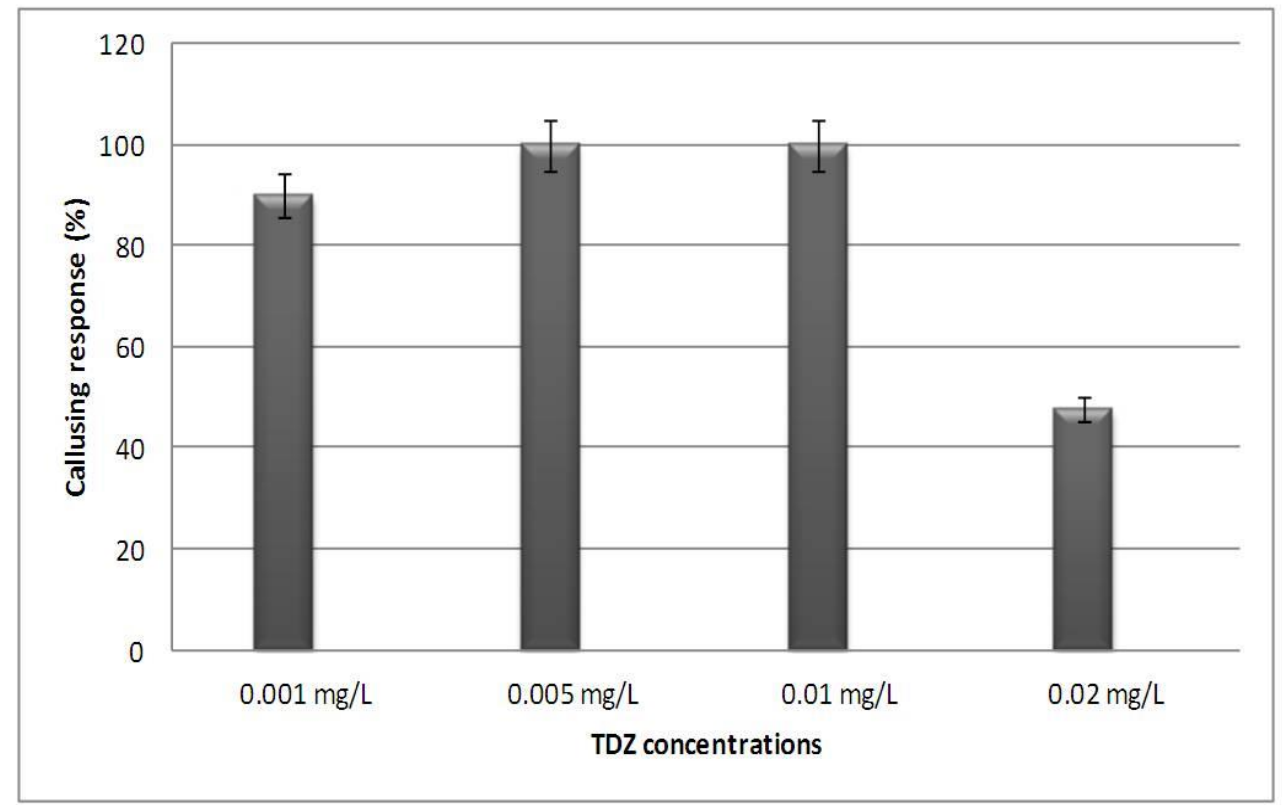

Figure 1. Callusing response (\%) of leaf explants on MS media supplemented with different concentrations of TDZ. 


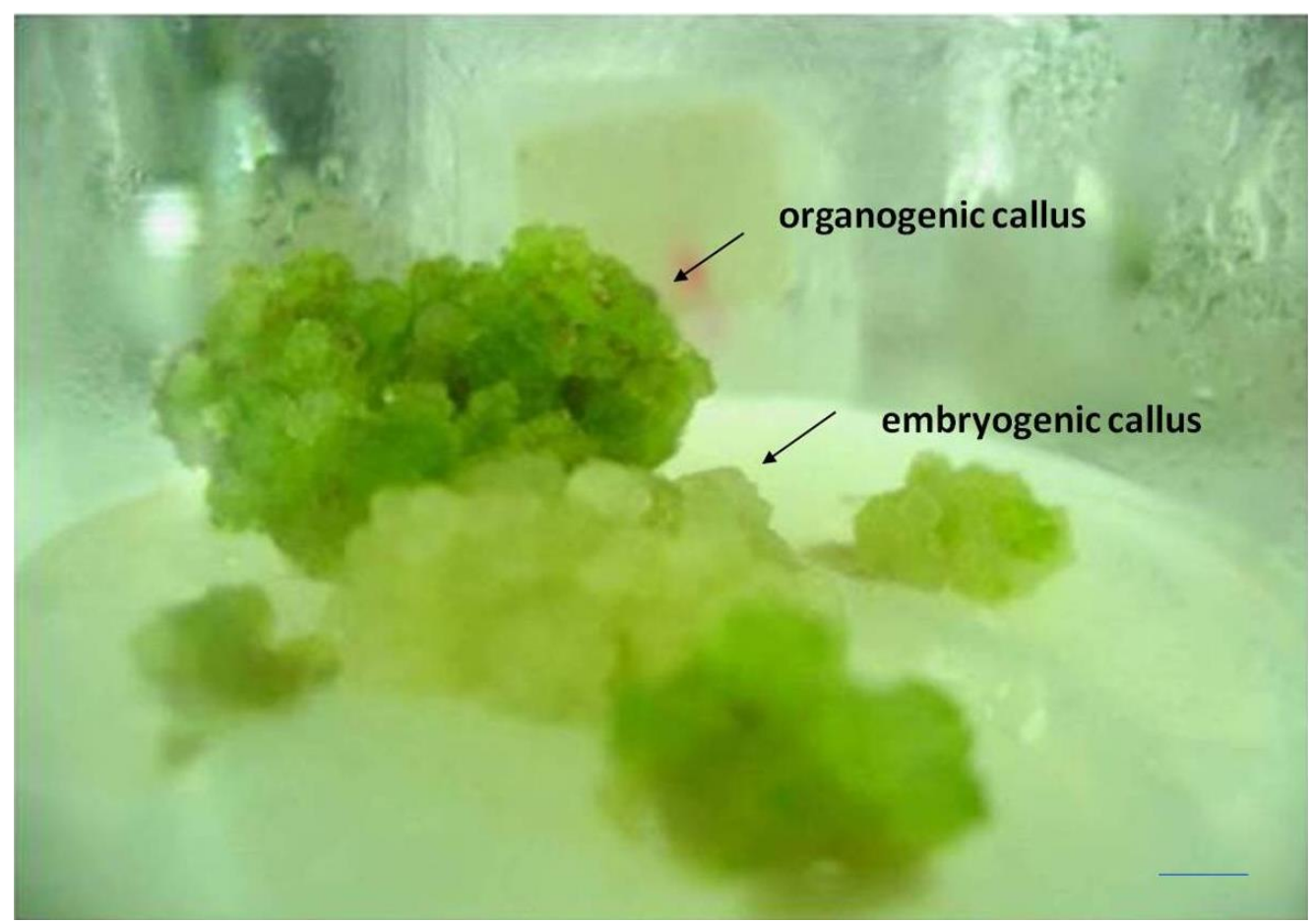

Figure 2. Organogenic and embryogenic calli on MS medium supplemented with $0.005 \mathrm{mg} / \mathrm{LTDZ}$. Bar: $1 \mathrm{~cm}$

Callus formation were also observed in media containing BA and KIN. Callusing response were $52.5 \%$ in $0.5 \mathrm{mg} / \mathrm{L} \mathrm{BA}, 27.5 \%$ in $1 \mathrm{mg} / \mathrm{L} \mathrm{BA}$ and $35 \%$ in $2 \mathrm{mg} / \mathrm{LBA}$ (Figure 3). In the media having kinetin, callusing was observed lower ratios. Callusing response were $5 \%$ in $0.2 \mathrm{mg} / \mathrm{LKIN}, 2.5 \%$ in $0.5 \mathrm{mg} / \mathrm{L} \mathrm{KIN,} 4 \%$ in 1 $\mathrm{mg} / \mathrm{LKIN}$. Callus formation was not observed in the MS medium containing $2 \mathrm{mg} / \mathrm{L} \mathrm{KIN}$.

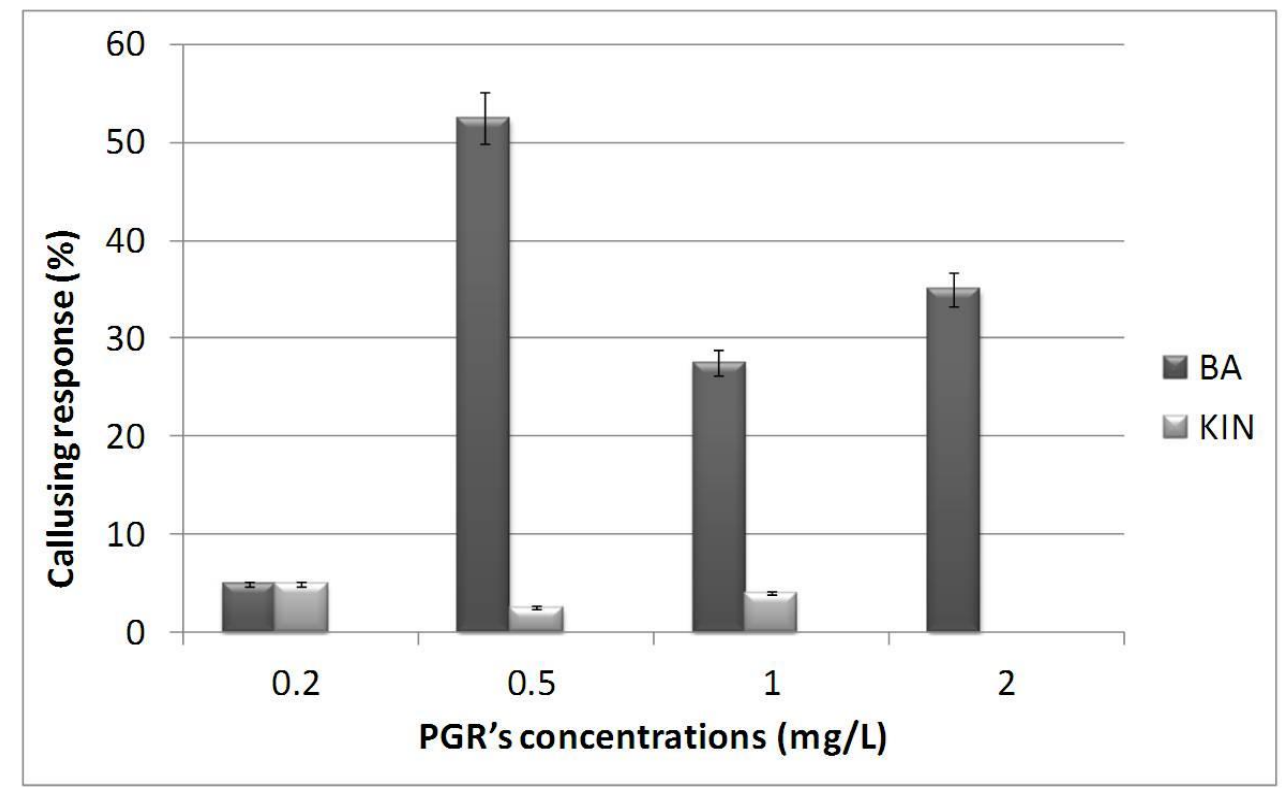

Figure 3. Callusing response (\%) of leaf explants on MS media supplemented with different concentrations of BA and KIN

No shoot differenttiation has been observed in calli held from the media containing TDZ and BA (except $0.2 \mathrm{mg} / \mathrm{L} \mathrm{BA}$ ). Although the low percentage of callus formation in $0.2 \mathrm{mg} / \mathrm{L} \mathrm{BA}$ added medium (5\%), 
this cytokinin type is found non-efficient for direct adventitious shoot proliferation as organogenic response occurs with only shoot buds and this case continues in the subcultures.

In adventitious shoot induction experiments, well developed shoots were observed only MS media supplemented with KIN at the end of sixth week. In the media having direct shoot regeneration, calli formation in explants on their surfaces having contact with the medium were observed but these calli became brownish in time and showed no activity.

The highest number of shoot per explant was obtained from the medium containing $1 \mathrm{mg} / \mathrm{L}$ KIN (Figure 4). The highest average of maximum shoot length $(4.17 \mathrm{~cm})$ was also observed in this medium (Figure 5).. There is no eminent difference in number of shoots from other media.

The shoots from adventitous shoot formation experiments were transferred to MS and $1 / 2$ MS media containing $0.5,1,2$ and $5 \mathrm{mg} / \mathrm{L}$ IAA, IBA, NAA for rooting. There was no difference between MS and $1 / 2 \mathrm{MS}$ media in rooting but it was very low and only $15 \%$ of total shoots could rooted in medium containing $0.5 \mathrm{mg} / \mathrm{L}$ IBA.

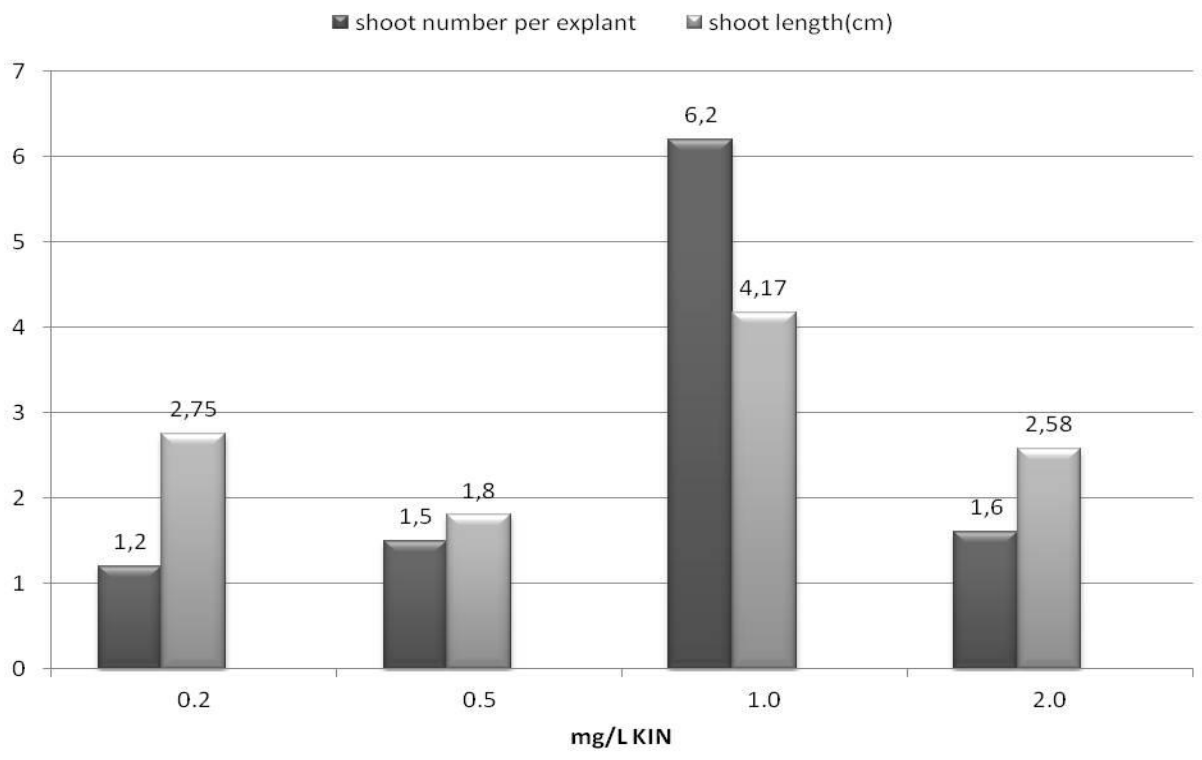

Figure 4. The effect of KIN on shoot number per explant and shoot length 


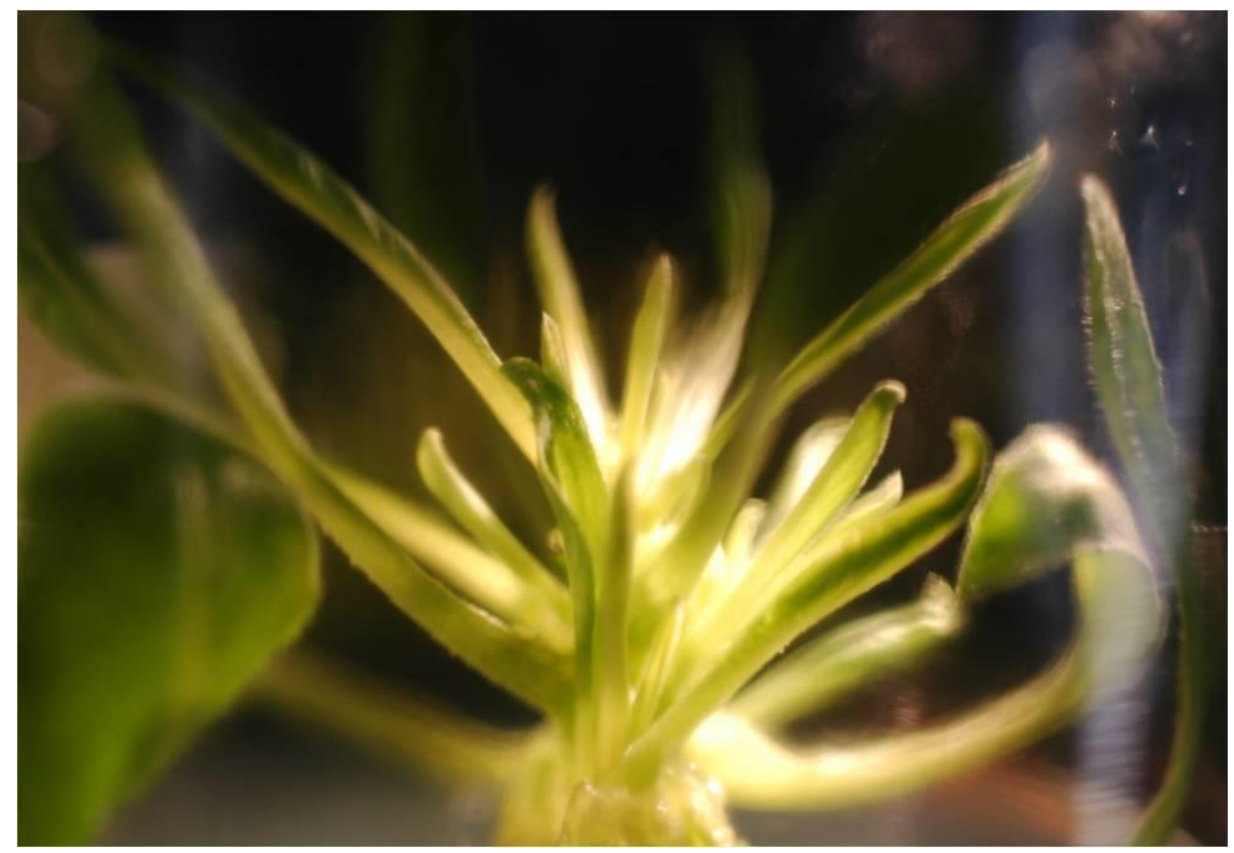

Figure 5. Adventitious shoots on MS media supplemented with $1 \mathrm{mg} / \mathrm{L} \mathrm{KIN}$

\section{4.}

\section{Discussion and Conclusion}

The results of callus formation and adventitious shoot regeneration were obtained from in vitro-grown plants. There are several advantages of regeneration from leaves derived from in vitro grown young seedlings: Surface sterilization of explants is not required since they are obtained from seedlings grown under aseptic conditions. The seeds using as initial materials to held leaves are also representative of the genetic structure of the target population to be conserved [16].

Callus was not induced when the explants were cultured on MS medium devoid of any growth regulators. When the leaf explants were inoculated on MS media supplemented with cytokinins callus formation was observed. Although auxins are known to be applied to induce callus, cytokinins can also induce in some other plants [17 and 18]. Cölgecen et al. [19] reported that application of cytokinins were more effective on the callus induction in Centaurea tchihatcheffii Fisch. \& C.A. Mey than auxins.

During the experiments, different structure calli types were observed: embryogenic and organogenic. As known well, a combination of auxine: cytokinin is required for embryogenic callus induction. The different pieces of same explants give different responses in spite of they have similar growth regulator content. This situation observed our experiments may be resulted from explant source and/or amount of endogenic plant growth regulators. Additionally, oxidative stress caused by cutting (during explant preparation) may cause embryogenic callus formation. The relationship among cell differentiation process, excessive $\mathrm{H}_{2} \mathrm{O}_{2}$ accumulation due to oxidative stress, reactive oxygen species (ROS) and enzymes that detoxify them have been demonstrated by Kairong et al. [20] and Emek and Erdağ [21] but further studies on this subject are required.

Callus formation were also observed in media containing BA and KIN. Callus formation is an intermediate and relatively undesirable stage that may indicate somaclonal variation in adventitious shoot regeneration studies. This stage may also be a promising process for biotechnological uses of $C$. zeybekii. It is known that induction and production of callus is the first and the most fundamental step to produce secondary metabolites via biotechnological methods [22and 23]. 
No shoot differenttiation has been observed in calli held from the media containing TDZ and BA (except $0.2 \mathrm{mg} / \mathrm{L} \mathrm{BA}$ ). BA was also reported as an effective cytokinin on axillary shoot proliferation of other endemic and threatened Centaurea species including also C. zeybekii $[7,8,9]$. Although the low percentage of callus formation in $0.2 \mathrm{mg} / \mathrm{L} \mathrm{BA}$ added medium (5\%), this cytokinin type is found non-efficient for direct adventitious shoot proliferation as organogenic response occurs with only shoot buds and this case continues in the subcultures.

In adventitious shoot induction experiments, well developed shoots were observed only MS media supplemented with KIN at the end of sixth week. There is no eminent difference in number of shoots from other media.

Finally, it is possible to stress that medium containing $1 \mathrm{mg} / \mathrm{L} \mathrm{KIN}$ is the best medium by obtaining highest number of shoots per explant and maximum shoot length for direct adventitous shoot regeneration with explants from in vitro germinated shoot leaves

There was no difference between MS and $1 / 2$ MS media in rooting but it was very low and only $15 \%$ of total shoots could rooted in medium containing $0.5 \mathrm{mg} / \mathrm{L} \mathrm{IBA}$. The low percentage of shoot rooting was also recorded in other reports on Centaurea species [6, 7, 24].

In this paper we reported the effect of different cytokinins on callus induction and adventitious shoot regeneration from leaf segments of from in vitro grown C. zeybekii seedlings as a contribution to its conservation efforts and biotechnological uses in future.

\section{References}

[1]. Ekim, T., Koyuncu, M., Vural, M., Duman, H., Aytaç, Z., Adıgüzel, N., "Türkiye Bitkileri Kırmızı Kitabı (Egrelti ve Tohumlu Bitkiler)”, Türkiye Tabiatını Koruma Dernegi, Ankara, 2000.

[2]. Fay, M.F., "Conservation of rare and endangered plants using in vitro methods" In vitro Cellular \& Developmental Biology-Plant, 28, 1-4, 1992.

[3]. Fay, M.F., "In what situation is in vitro culture appropriate to plant conservation?" Biodiversity and Conservation, 3, 176-183, 1994.

[4]. Iriando, J.M., Perez C., "Application of in vitro culture techniques to the conservation of Iberian endemic endangered plant species" Botanic Gardens Micropropagation News, 1, 4-6, 1990.

[5]. Wochock, Z.S., "The role of tissue culture in preserving threatened and endangered plant species" Biological Conservation, 20, 83-89, 1981.

[6]. Cuenca, S., Amo- Marco, J.B., Para, R., "Micropropagation from inflorescense stems of the Spanish endemic plant Centaurea paui Loscos ex Wilk. (Compositae)" Plants Cell Reports, 18, 674-679, 1998.

[7]. Hammat, N., Evans, P.K., "The in vitro propagation of an endangered species: Centaurea junoniana Svent. (Compositae)" Horticultural Science, 60, 93-97, 1985.

[8]. Iriondo J.M., Perez C., "Micropropagation and in vitro strage of Centaurium rigualii Esteve (Gentianaceae)" Israel Journal of Plant Sciences, 44, 115-123, 1996.

[9]. Kurt S., Erdağ B., "In vitro germination and axillary shoot propagation of Centaurea zeybekii" Biologia-Section Botany, 64, 97-101, 2009. 
[10]. Gurbuz I., Yesilada E., "Evaluation of antiulcerogenic effect of sesquiterpene lactones from Centaurea solstitialis L. ssp. solstitialis by using various in vivo and biochemical techniques" Journal of Ethnopharmacology, 112, 284- 91, 2007.

[11]. Robles M., Wang N., Kim R., Choi B.H., "Cytotoxic effects of repin, a principal sesquiterpene lactone of Russian knapweed” Journal of Neuroscience Research, 47, 90- 97, 1997.

[12]. Rusak G., Krajac'ic M., Ples'e N., “ Inhibition of tomato bushy stunt virus infection using a quercetagetin flavonoid isolated from Centaurea rupestris L”Antiviral Research, 36, 125-129, 1997.

[13]. Altıntaş A., Tugay B., Demirci K., Başer H.C., "Composition of the essential oils of Centaurea diffusa Lam. and Centaurea zeybekii Wagenitz" WOCMAP IV (World Conference on Medicinal and Aromatic Compounds), 9-14 November, Abstract Book, 477 pp, Cape Town, South Africa, 2008.

[14]. Kurt S., Erdağ B., Karagözler A.A., Uygun M., Centaurea zeybekii Wagenitz (Asteraceae)'nin antioksidan aktivitesi üzerine bir araştırma" 19. Ulusal Biyoloji Kongresi, 23-27 Haziran, Bildir özet kitab1, s. 413, Trabzon, 2008.

[15]. Murashige T., Skoog F., "A revised medium for rapid growth and bioassays with tobacco tissue culture" Plant Physiology, 15, 437-497, 1962.

[16]. Merciey H., Kerbauy G.B., 1997 "Micropropagation of ornamental bromeliads (Bromeliaceae)" Biotechnology in Agriculture and Forestry, 40, 43-57, 1997.

[17]. Babaoğlu M., Gurel E., Ozcan S., "Plant Biotechnology, Tissue Culture and Application”, Selçuk University Press, Turkey, pp. 374, 2002.

[18]. Ikeuchi M., Sugimoto K., Iwase A., "Plant Callus: Mechanisms of Induction and Repression" The Plant Cell, 25, 3159-3173, 2013.

[19]. Cölgecen H., Koca U., Yagc1 C., Toker G., Toker MC., "Callus induction and secondary metabolite production studies in Centaurea tchihatcheffii Fisch. \& C. A. Mey" Journal of Pharmaceutical Sciences, 37, 9-16, 2012.

[20]. Kairong C., Ji L., Gengmei X., Jianlong L., Lihong W., Yafu W., "Effect of hydrogen peroxide on synthesis of proteins during somatic embryogenesis in Lycium barbarum" Plant Cell Tissue \& Organ Culture, 68, 187-193, 1999.

[21]. Emek Y., Erdag B.," In vitro somatic embryogenesis and antioxidant enzyme activities in Rhaponticoides mykalea (Hub.-Mor.) M. V. Agab. \& Greuter critically endangered endemic plant" Fresenius Environmental Bulletin, 23, 1051-1057, 2014.

[22]. Luczkiewicz M., Zarate R., Dembinska-Migas W., Migas P., Verpoorte R., "Production of pulchelin E in hairy roots, callus and suspension cultures of Rudbeckia hirta L.” Plant Science, 163, 91-100, 2002.

[23]. Luczkiewicz M., Glod D., "Callus cultures of Genista plants - in vitro material producing high amounts of isoflavones of phytoestrogenic activity” Plant Science, 165, 1101-1108, 2003.

[24]. Ozel C.A., Khawar K. M., Mirici S., Ozcan S., Arslan O., "Factors affecting in vitro plant regeneration of the critically endangered Mediterranean knapweed (Centaurea tchihatcheffii Fisch et. Mey.) Naturwissenschaften 93, 511-517, 2006. 